\title{
Identification and expression of differentially expressed genes in the hard clam, Mercenaria mercenaria, in response to quahog parasite unknown (QPX) Mickael Perrigault ${ }^{1}$, Arnaud Tanguy ${ }^{2}$ and Bassem Allam*1
}

\begin{abstract}
Address: ${ }^{1}$ School of Marine and Atmospheric Sciences, Stony Brook University, Stony Brook. NY 11794-5000, USA and 2 UPMC Université Paris 6, UMR 7144, Equipe Génétique et Adaptation en Milieu Extrême, Station Biologique de Roscoff, 29682 Roscoff, France and UPMC Université Paris 6, UMR 7138, Systématique, Adaptation et Evolution, 75005 Paris, France

Email: Mickael Perrigault - mperriga@ic.sunysb.edu; Arnaud Tanguy - atanguy@sb-roscoff.fr; Bassem Allam* - Bassem.Allam@stonybrook.edu

* Corresponding author
\end{abstract}

Published: 14 August 2009

BMC Genomics 2009, 10:377 doi:10.1186/147|-2164-10-377
Received: 5 March 2009

Accepted: 14 August 2009

This article is available from: http://www.biomedcentral.com/I47I-2/64/I0/377

(c) 2009 Perrigault et al; licensee BioMed Central Ltd.

This is an Open Access article distributed under the terms of the Creative Commons Attribution License (http://creativecommons.org/licenses/by/2.0), which permits unrestricted use, distribution, and reproduction in any medium, provided the original work is properly cited.

\begin{abstract}
Background: The hard clam, Mercenaria mercenaria, has been affected by severe mortality episodes associated with the protistan parasite QPX (Quahog Parasite Unknown) for several years. Despite the commercial importance of hard clams in the United States, molecular bases of defense mechanisms in $M$. mercenaria, especially during QPX infection, remain unknown.

Results: Our study used suppression subtractive hybridization (SSH), as well as the construction of cDNA libraries from hemocytes to identify genes related to the defense of the hard clam against its parasite. Hard clams were experimentally infected with QPX and SSH was performed on mRNA samples extracted from mantle and gill tissues at different times post-challenge. A total of 298 clones from SSH libraries and 1352 clones from cDNA libraries were sequenced. Among these sequences, homologies with genes involved in different physiological processes related to signal transduction, stress response, immunity and protein synthesis were identified. Quantitative PCR revealed significant changes in the expression of several of these genes in response to QPX challenge and demonstrated significant correlations in terms of levels of gene expression between intermediates of signalling pathways and humoral defense factors, such as big defensin and lysozyme.

Conclusion: Results of this study allowed the detection of modifications caused by QPX at the transcriptional level providing insight into clam immune response to the infection. These investigations permitted the identification of candidate genes and pathways for further analyses of biological bases of clam resistance to QPX allowing for a better understanding of bivalve immunity in general.
\end{abstract}

\section{Background}

The hard clam, Mercenaria mercenaria, is exploited along the eastern coast of North America, from Maritime Canada to the Gulf of Mexico. This species is among the most commercially important bivalves in the United States and is well suited for aquaculture as it is characterized by a relatively fast growth. The hard clam is a sturdy bivalve and the only infectious agent that causes severe mortality epi- 
sodes among wild and cultured clams is the protistan parasite QPX (Quahog Parasite Unknown) [1]. QPX is a unicellular protist member of the family Thraustochytridae [2]. Despite the ubiquitous nature of this family in aquatic environment, thraustochytrids were poorly studied and only few pathogens were described in this group [3]. QPX reported in 1989 at Prince Edward Island was linked to almost $100 \%$ of the mortality among cultured clams [4]. It was subsequently identified in other locations further south: Massachusetts in 1995 [5], Virginia in 1996 [6], New Jersey [7] and New York [8] in 2002, but the parasite was never detected further south than Virginia. Recent lab-controlled experiments [9] and in situ investigations $[7,10]$ demonstrated variability of susceptibility among hard clam populations, with clams from southern broodstocks being more susceptible to QPX disease than northern broodstocks, suggesting a genetic origin of clam resistance. Field investigations also showed variability in the resistance toward QPX among different local (New York State) clam broodstocks [9]. Differences of susceptibility to pathogen infection between different populations were previously observed in other bivalves $[11,12]$. Intra-specific genetic variation in disease susceptibility to Perkinsus marinus was indirectly demonstrated by the evolution of resistance in disease-challenged natural populations of oysters [13].

Like other invertebrates, bivalves lack adaptive immunity and instead rely on various innate defenses against invading pathogens. In hard clam, hemocytes constitute the primary line of defense against materials recognized as nonself [14]. The presence of non-self materials in tissues initiates a complex molecular signalling cascade to stimulate cell-mediated immune responses, mainly involving phagocytosis or encapsulation of foreign materials, and the production of reactive oxygen species (ROS) $[15,16]$. Humoral factors, such as defensins, also play an important role because they possess various anti-microbial properties $[17,18]$. Enzymes, such as peptidases and lysozyme, are particularly crucial because of their ability to hydrolyze protein components of invading microorganisms [19-21]. Since bivalves have an open circulatory system, antimicrobial constituents associated with plasma and hemocytes are virtually present in all tissues. Histological observation of naturally- and experimentallyinfected clams by QPX demonstrated that some individuals are sometimes able to mount a defense reaction characterized by an intense inflammatory response, phagocytosis (rare) and encapsulation of parasite cells. The presence of dead and necrotic QPX cells was reported in some instances, suggesting that clam's humoral and/or cellular response was sufficiently efficient to lead to the healing of infected individuals $[6,8,22]$. Histological observations of infected clam tissues and in vitro cultures also revealed an abundant production of a mucofilamen- tous net by QPX. These secretions are suspected to represent virulence factors that protect the parasite from host defense mechanisms [5]. In vitro investigations demonstrated that the mucus layer protects QPX from humoral defense factors in clam plasma and therefore, could be important to the establishment, as well as the development, of the disease [23]. However, clam immune response to QPX cells and/or mucus has never been investigated.

In bivalves, prior studies focusing on the identification of immune-related genes were performed in oysters [24-28], mussels [29] and scallops [30-34]. Molecular bases of defense mechanisms in hard clams, especially during QPX infection, are unknown. The only investigations that have studied molecular aspects of clam immunity were performed in the genus Tapes or Ruditapes; [35-37], a relatively distant member of the family Veneridae. Identification of immune-related genes involved in the response of M. mercenaria to QPX infection could lead to the development of tools that will contribute to the selection of resistant populations of clams and develop knowledge about clam immunity by the generation of a nucleic database for the species.

This study aimed for a better characterization of clam's response to QPX infection by investigating differentially expressed genes following parasite challenge. Our study is the first to apply transcriptomic approaches in M. mercenaria. Suppression subtractive hybridization ( $\mathrm{SSH}$ ), as well as the construction of cDNA libraries of expressed genes associated with quantitative PCR, was used to identify genes related to the defense of hard clam against its parasite.

\section{Results \\ Identification of regulated genes in SSH libraries}

The search for homology using the BLASTX program revealed a total of 25 unique sequences in gill libraries and 29 unique sequences in mantle libraries for M. mercenaria after 14 days of exposure, 10 unique sequences in gill libraries and 74 unique sequences in mantle libraries for M. mercenaria after 48 days of exposure, including sequences corresponding to known genes or unidentified ESTs. Genes regulated by QPX challenge were assigned to 7 major cellular physiological functions using the Gene Ontology (GO) Database: 1) stress response and detoxification; 2) cell communication, immune system and membrane receptors; 3 ) cell cycle regulation, DNA repair, protein regulation and transcription; 4) cytoskeleton production and maintenance; 5) respiratory chain; 6) metabolism; 7) ribosomal proteins; 8) unknown functions and 9) unidentified sequences. Up-regulated and down-regulated sequences in gill and mantle tissues are listed in tables 1 and 2, respectively. Sequences were submitted to 
Table I: Upregulated genes identified in mantle and gill tissues I4 and 48 days after challenge with washed and unwashed QPX cells.

\begin{tabular}{|c|c|c|c|c|}
\hline Homolog proteins & Homolog species & Blast $X$ value & Libraries & GenB \\
\hline \multicolumn{2}{|c|}{ stress response and detoxification } & \multicolumn{3}{|c|}{$\begin{array}{l}4 \% \text { of sequences identified in libraries from mantle tissue } \\
11 \% \text { of sequences identified in libraries from gill tissue }\end{array}$} \\
\hline metallothionein & Corbicula fluminea & $|e-I|$ & Mantle (14 days) & GO915213 \\
\hline cytochrome P450 like TBP & Nicotiana tabacum & $2 e-07$ & Gills (14 days) & G0915227 \\
\hline $71 \mathrm{kDa}$ heat shock protein & Haliotis tuberculata & $6 e-53$ & Mantle (48 days) & GO915235 \\
\hline ferritin subunit & Meretrix meretrix & $3 e-50$ & Mantle (48 days) & G0915233 \\
\hline
\end{tabular}

cell communication, immune system and membrane $7 \%$ of sequences identified in libraries from mantle tissue receptors

receptor of Activated Kinase C I

lysozyme (Chain)

big defensin

sialic acid binding lectin

C-type lectin A

nicotinic acetylcholine receptor subunit type $\mathrm{H}$

Mya arenaria

Enterobacteria phage T4

Tachypleus tridentatus

Helix pomatia

Chlamys farreri

Lymnaea stagnalis

cell cycle regulation, DNA repair, protein regulation and transcription

CCAAT/enhancer binding

Aplysia kurodai

protein

translation elongation factor I-

alpha

elongation factor I beta

eukaryotic translation

elongation factor I delta

similar to $\mathrm{H} 3$ histone, family 3B Macaca mulatta

cytoskeleton production and maintenance

Actin

myosin (essential light chain)

Tropomyosin

alpha tubulin

beta-tubulin

transgelin 3

\section{respiratory chain}

cytochrome oxidase subunit I

cytochrome oxidase subunit 3

NADH dehydrogenase subunit 4

ATP synthase subunit 6

\section{Metabolism}

zinc-dependent alcohol

dehydrogenase

\section{ribosomal proteins}

ribosomal protein LI7A

ribosomal protein LII

ribosomal protein $\mathrm{S} 2 \mathrm{e}$

ribosomal protein $\mathrm{S} 3 \mathrm{a}$

unknown functions
Chlamys farreri

Macrocallista nimbosa

Balanus rostratus

Leishmania braziliensis

Halocynthia roretzi

Danio rerio

Ruditapes philippinarum

Inocellia crassicornis

Ruditapes philippinarum

Ruditapes philippinarum

Lysiphlebus testaceipes

Argopecten irradians Ictalurus punctatus

Onchocerca volvulus

Crassostrea gigas
$4 e-44$

Mantle (48 days)

GO915258

$3 e-04$

5 e- 10

le- 04

$5 e-05$

$8 \mathrm{e}-14$

Mantle (48 days)

Mantle (48 days)

Mantle (48 days)

Mantle (14 days)

Mantle (14 days)

GO915259

GO915266

GO915267

GO915219

$\underline{\mathrm{GO} 915224}$

$4 \%$ of sequences identified in libraries from mantle tissue $26 \%$ of sequences identified in libraries from gill tissue

5e-19 Mantle (14 days)

$\mathrm{GO915218}$

3e-108 Mantle (14 and 48 days) and

GO915211

Gills (48 days)

4e-2I Mantle (48 days)

GO915246

4e- 12 Mantle (48 days)

GO915241

9e-37 Mantle (48 days)

G0915263

$4 \%$ of sequences identified in libraries from mantle tissue $1 \%$ of sequences identified in libraries from gill tissue

$4 \mathrm{e}-67$

Mantle (48 days)

GO915239

$3 e-38$

Mantle (48 days)

GO915247

$7 \mathrm{e}-15$

Mantle (48 days)

GO915261

$2 \mathrm{e}-05$

Mantle (48 days)

GO915252

$2 \mathrm{e}-59$

Gills ( 14 days)

GO915225

le-08

Mantle (48 days)

GO915232

$12 \%$ of sequences identified in libraries from mantle tissue $11 \%$ of sequences identified in libraries from gill tissue

2e-29

Mantle and Gills

GO915255

$3 e-19$

(14 and 48 days)

$3 e-30$

Mantle ( 14 and 48 days)

GO915234

Mantle and Gills (48 days)

GO915245

$3 e-25$

Mantle and Gills ( 14 days)

$\underline{\mathrm{GO} 915223}$

$6 \%$ of sequences identified in libraries from gill tissue

le-33 Gills (14 days)

$\underline{\mathrm{GO}} 15228$

$3 \%$ of sequences identified in libraries from mantle tissue $1 \%$ of sequences identified in libraries from gill tissue

$8 \mathrm{e}-11$ Mantle (48 days)

GO915262

$2 \mathrm{e}-08$

Mantle (48 days)

GO915248

$8 \mathrm{e}-25$

Gills (48 days)

GO915270

5 e- 99

Mantle (14 days)

$\underline{\mathrm{GO}} 15220$

$1 \%$ of sequences identified in libraries from mantle tissue

$29 \%$ of sequences identified in libraries from gill tissue 
Table I: Upregulated genes identified in mantle and gill tissues 14 and 48 days after challenge with washed and unwashed QPX cells.

\begin{tabular}{|c|c|c|c|c|}
\hline $\begin{array}{l}\text { putative senescence-associated } \\
\text { protein }\end{array}$ & Pisum sativum & $3 e-34$ & Gills (14 days) & G09|523| \\
\hline $\begin{array}{l}\text { hypothetical protein } \\
\text { TTHERM_02141640 }\end{array}$ & $\begin{array}{l}\text { Tetrahymena thermophila } \\
\text { SB2 } 10\end{array}$ & $2 e-36$ & Gills (14 days) & GO915230 \\
\hline $\begin{array}{l}\text { hypothetical protein } \\
\text { TTHERM_00648850 }\end{array}$ & $\begin{array}{l}\text { Tetrahymena thermophila } \\
\text { SB2 I0 }\end{array}$ & $8 e-09$ & Mantle (48 days) & GO915260 \\
\hline SJCHGC09076 protein & Schistosoma japonicum & $4 e-03$ & Mantle (48 days) & $\underline{G 0915249}$ \\
\hline \multirow{2}{*}{\multicolumn{2}{|c|}{ unknown genes }} & \multicolumn{3}{|c|}{$16 \%$ of sequences identified in libraries from mantle tissue } \\
\hline & & \multicolumn{3}{|c|}{ II\% of sequences identified in libraries from gill tissue } \\
\hline 7 sequences & & & Mantle ( 14 days) & $\frac{\mathrm{GO9} 15212, \frac{\mathrm{GO} 915214-17}{\mathrm{GO} 915221-2}}{}$ \\
\hline 15 sequences & & & Mantle (48 days) & $\frac{\text { GO9I5236-38, }}{40}, \underline{42-44}, \underline{50-51}$, \\
\hline 2 sequences & & & Gills (I4 days) & GO915226, GO915229 \\
\hline 4 sequences & & & Gills (48 days) & GO915268-69, GO915271-72 \\
\hline
\end{tabular}

NCBI with the following accession numbers: [GenBank: GO915165 GO915272].

\section{Identification of genes from hemocyte cDNA libraries}

The sequencing of 1352 clones from the hemocyte cDNA library resulted in the characterization of a total of 487 ESTs that have been clusterized according to their function using the GO Database (Figure 1). Only 29\% of these ESTs present an annotation and $71 \%$ remain unidentified. Several sequences presenting homologies with stress- and defense-related genes have been detected including StressInduced Protein STI [GenBank: GR209325] (BlastX value $=8 \mathrm{e}^{-21}$, Cryptosporidium parvum - [GenBank: XP 001388209]), Toll-Like Receptor TLR [GenBank: GR209327] (BlastX value $=2 e^{-4}$, Strongylocentrotus purpuratus - [GenBank: XP 001201188]), Tumor Necrosis Factor Receptor-Associated Factor TRAF-6 [GenBank: GR209326] (BlastX value $=4 \mathrm{e}^{-5}$, Chlamys farreri $-[\mathrm{Gen}-$ Bank: ABC73694]) and C1q - TNF related protein [GenBank: GR209324] (BlastX value $=3 e^{-2}$ Danio rerio [GenBank: NP 001017702]).

\section{Expression patterns of differentially-regulated genes}

Results showed that QPX challenge induced significant changes in the expression of several of the eighteen investigated genes. This modulation was characterized by a highly variable regulation of these genes 14 days after challenge (Figure 2). At that sampling time, few transcripts were significantly regulated, particularly in w-QPX challenged clams, including hemocyte defensin, $\mathrm{C} 1 \mathrm{q}$, actin, HSP 70 and ferritin (Table 3). After 28 and 48 days, significant variations of gene expression were observed in both washed and unwashed-QPX challenged clams with a high variability according to the challenge and the tissue (Table 3, Figure 2). Some genes, such as TRAF-6, were more specific to the challenge (washed or unwashedQPX), whereas other genes tended to be more linked to particular tissues such as the big defensin (Figure 2). In addition, some gene expressions presented continuous trends over time (decrease or increase) as TRAF- 6 and ferritin, while other genes displayed strong modulation after 28 days (TLR expression in mantle tissues, Figure 2). Multifactor analysis indicated significant effects of all individual parameters (time, treatment and tissues) on actin and big defensin expression and a significant effect of combined parameters on AP-1, lysozyme and TLR expression (Table 4).

Discriminant Analysis performed on data from mantle and gill tissues (samples from different time points combined) revealed significant discrimination of the treatments in both tissues by Function 1 ( $p=0.05$ and 0.01 , respectively) which explained $68.3 \%$ and $81.5 \%$ of the total variance respectively (Table 5). Scatter plots of discriminant functions indicated a small overlapping between treatments with a good discrimination of centroids by Function 1 (Figure 3). Examination of the structure correlation matrix (Table 6) revealed that 9 variables were highly loaded in Function 1 for both mantle and gill tissue analyses. Among these variables, the expression of TLR, AP-1, big defensin and lysozyme were highly correlated (Table $7, p<0.001$ ).

\section{Discussion}

Our investigations allowed the identification of components involved in different physiological processes related to signal transduction (RACK-1, TLR, TRAF-6), stress response (HSP, metallothionein, ferritin), immunity (lectins, defensins, lysozyme) and protein synthesis (transcription and elongation factors). This new information allowed the detection of modifications caused by QPX at the transcriptional level. Our results depict some integrative aspects of clam responses to QPX infection and more specifically to different forms of QPX challenges (washed versus unwashed cells of the parasite).

Since QPX is an opportunistic parasite usually found in pallial tissues (gills and mantle) of infected clams [7], we 
Table 2: Downregulated genes identified in mantle and gill tissues I 4 and 48 days after challenge with washed and unwashed QPX cells.

\begin{tabular}{|c|c|c|c|c|}
\hline Homolog proteins & Homolog species & Blast $X$ value & Libraries & GenBank accession no \\
\hline \multicolumn{2}{|c|}{ stress response and detoxification } & \multicolumn{3}{|c|}{$8 \%$ of sequences identified in libraries from mantle tissue } \\
\hline HSP70 & Mytilus galloprovincialis & le-52 & Mantle (14 days) & G0915169 \\
\hline 7I kDa heat shock protein & Haliotis tuberculata & $6 e-53$ & Mantle (14 days) & $\underline{G 0915166}$ \\
\hline \multicolumn{2}{|c|}{$\begin{array}{l}\text { cell communication, immune system and membrane } \\
\text { receptors }\end{array}$} & \multicolumn{3}{|c|}{$5 \%$ of sequences identified in libraries from mantle tissue } \\
\hline hemocyte defensin & Crassostrea gigas & le-05 & Mantle (48 days) & G0915199 \\
\hline $\begin{array}{l}\text { peroxisome proliferator- } \\
\text { activated receptor }\end{array}$ & Oncorhynchus keta & $7 e-07$ & Mantle ( 14 and 48 days) & $\underline{\mathrm{GO}} 15177$ \\
\hline thioester-containing protein & Euphaedusa tau & $2 e-08$ & Mantle (48 days) & $\underline{\mathrm{GO}} 15190$ \\
\hline \multicolumn{2}{|c|}{$\begin{array}{l}\text { cell cycle regulation, DNA repair, protein regulation and } \\
\text { transcription }\end{array}$} & \multicolumn{3}{|c|}{$3 \%$ of sequences identified in libraries from mantle tissue } \\
\hline transcription factor AP-I & Strongylocentrotus purpuratus & $2 \mathrm{e}-16$ & Mantle (48 days) & $\underline{G 0915178}$ \\
\hline $\begin{array}{l}\text { translation elongation factor I- } \\
\text { alpha }\end{array}$ & Dreissena polymorpha & $3 e-108$ & Mantle ( 14 and 48 days) & $\underline{\mathrm{GO} 915167}$ \\
\hline \multicolumn{2}{|c|}{ cytoskeleton production and maintenance } & \multicolumn{3}{|c|}{$2 \%$ of sequences identified in libraries from mantle tissue } \\
\hline Actin & Cyrenoida floridana & le-82 & Mantle (48 days) & $\underline{\mathrm{GO}} 15201$ \\
\hline alpha tubulin & Theromyzon tessulatum & $5 e-40$ & Mantle (48 days) & G0915209 \\
\hline alpha tubulin al & Mesenchytraeus solifugus & le-09 & Mantle (48 days) & $\underline{\mathrm{GO}} 15208$ \\
\hline \multicolumn{2}{|l|}{ respiratory chain } & \multicolumn{3}{|c|}{$1 \%$ of sequences identified in libraries from mantle tissue } \\
\hline & & \multicolumn{3}{|c|}{ I\% of sequences identified in libraries from gill tissue } \\
\hline cytochrome b & Ruditapes philippinarum & $8 e-91$ & Gills (14 days) & GO915174 \\
\hline cytochrome c subunit I & Ruditapes philippinarum & $6 e-25$ & Mantle (14 days) & $\overline{\mathrm{GO} 915173}$ \\
\hline \multicolumn{2}{|l|}{ metabolism } & \multicolumn{3}{|c|}{ I\% of sequences identified in libraries from mantle tissue } \\
\hline ADP/ATP carrier & $\begin{array}{l}\text { Leishmania mexicana } \\
\text { amazonensis }\end{array}$ & $2 e-05$ & Mantle ( 14 days) & $\underline{\mathrm{GO}} 15170$ \\
\hline \multicolumn{2}{|l|}{ ribosomal proteins } & \multicolumn{3}{|c|}{$4 \%$ of sequences identified in libraries from mantle tissue } \\
\hline ribosomal protein L7 & Argopecten irradians & $8 e-03$ & Mantle (48 days) & G0915202 \\
\hline ribosomal protein LI9 & Crassostrea gigas & $9 e-21$ & Mantle (48 days) & G0915205 \\
\hline ribosomal protein L24 & Danio rerio & $3 e-12$ & Mantle ( 14 days) & $\underline{\mathrm{GO}} 15172$ \\
\hline \multicolumn{2}{|l|}{ unknown functions } & \multicolumn{3}{|c|}{$8 \%$ of sequences identified in libraries from mantle tissue } \\
\hline SJCHGC02792 protein & Schistosoma japonicum & $3 e-12$ & Mantle (14 days) & G0915171 \\
\hline $\begin{array}{l}\text { hypothetical protein } \\
\text { DDBDRAFT_016779I }\end{array}$ & Dictyostelium discoideum AX4 & le-04 & Mantle (14 days) & $\underline{G 0915168}$ \\
\hline hypothetical protein & Monodelphis domestica & $2 e-27$ & Mantle (48 days) & $\underline{\mathrm{GO}} 15196$ \\
\hline $\begin{array}{l}\text { similar to product in Drosophila } \\
\text { melanogaster }\end{array}$ & Schistosoma japonicum & $7 e-04$ & Mantle (48 days) & G0915187 \\
\hline \multicolumn{2}{|l|}{ unknown genes } & \multicolumn{3}{|c|}{$17 \%$ of sequences identified in libraries from mantle tissue } \\
\hline \multirow{2}{*}{\multicolumn{2}{|c|}{ L ceauence }} & \multicolumn{3}{|c|}{$3 \%$ of sequences identified in libraries from gill tissue } \\
\hline & & & Mantle (14 days) & $\underline{G O 915165}$ \\
\hline 23 sequences & & & Mantle (48 days) & 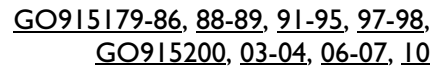 \\
\hline 2 sequences & & & Gills (14 days) & GO915175-76 \\
\hline
\end{tabular}

focused our investigations on these tissues to identify differentially expressed genes in response to the infection. Interestingly, the comparison of gene distribution from subtracted libraries indicated some variations according to the tissue and the time of sampling. After 14 days of QPX challenge, similar numbers of unique genes were identified in mantle and gill tissues. However, 48 days post-challenge, a clear difference was observed among tissues with a larger proportion of genes identified in mantle as compared to gills. In addition, $24 \%$ of identified genes in mantle tissues presented homologies with proteins known to be involved in stress and immune response, 


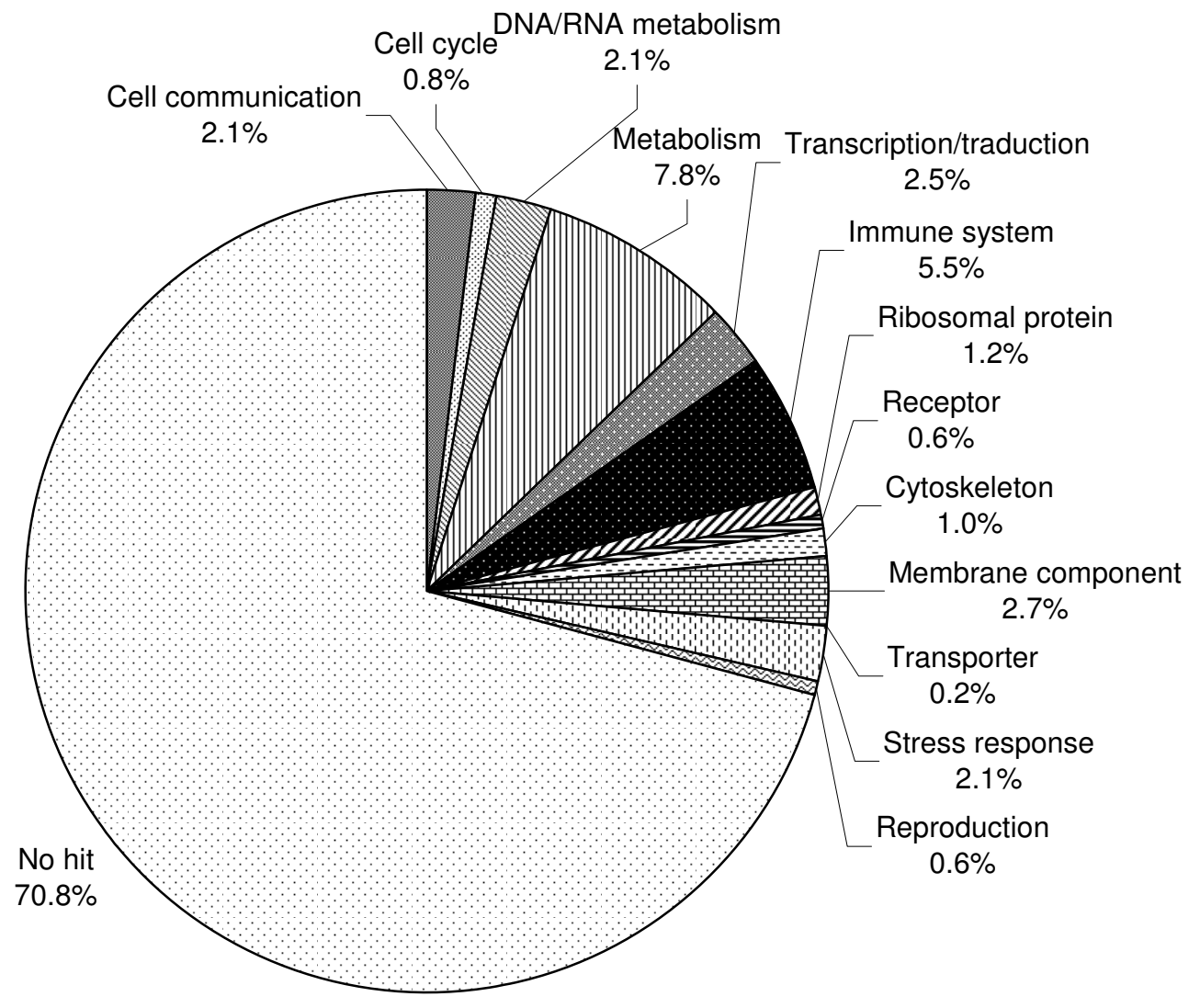

\section{Figure I}

Functional classification of the sequences identified in the hemocyte library (487 ESTs). Genes were clustered into 13 categories according to their putative biological function.

whereas only $11 \%$ of identified genes in gills were involved in stress response (Tables 1 and 2). These results suggest that molecular changes observed 14 days after challenge represented a systemic acute response of clams resulting from the injection of parasite in the circulation, whereas the differences observed after 48 days could be related to clam response to established QPX infections in mantle tissues. These results fit well with histological observations made following injection of QPX into the pericardial cavity of hard clams that showed an early (2 weeks) systemic distribution of QPX in clam tissues, followed by the development of most intense lesions in mantle tissues [22]. It is noteworthy that the development of QPX lesions following intrapericardial injection matches well, temporally (>4 weeks) and spatially (organs infected), with the typical disease development in naturally infected clams [22].

Our investigations demonstrated the modulation in QPXchallenged clams of components with strong homologies to stress-related proteins, including heat shock proteins (HSP's) and their co-chaperones STI1 (Stress Induced Pro- tein), metallothionein and ferritin. These molecular chaperones protect the cell and maintain homeostasis under stressful conditions [38]. HSPs were identified in several bivalve species in response to various chemical, physical and pathogenic stresses and appear to represent a general marker of non-specific stress [25,39-41]. Previous studies demonstrated that heat-shock proteins were able to stimulate innate immune system in mammalians [42]. Our results are consistent with previous studies, which showed that the relationship between HSP and defense response was not established, despite the identification of heatshock proteins following pathogenic challenge in invertebrates $[25,36,43]$. HSP 70 was significantly repressed in gill tissues of w-QPX challenged clams after 14 days and up-regulated in mantle tissues of u-QPX challenged clams (unwashed cells) after 28 days (Table 3 ). However, Multifactor ANOVA analysis indicated no significant role of HSP expression in the response of clams to the different treatments (Table 4). MT's are an ubiquitous class of metal-binding proteins that function in the homeostasis of essential metals, as well as serving a detoxification role by sequestering toxic metals. In oysters, Anderson et al. 
Table 3: Summary of the results of Student's t-tests of gene expression data.

\begin{tabular}{|c|c|c|c|c|c|c|c|c|c|c|c|c|}
\hline & \multicolumn{4}{|c|}{14 days } & \multicolumn{4}{|c|}{28 days } & \multicolumn{4}{|c|}{48 days } \\
\hline & \multicolumn{2}{|c|}{ Mantle } & \multicolumn{2}{|c|}{ Gills } & \multicolumn{2}{|c|}{ Mantle } & \multicolumn{2}{|c|}{ Gills } & \multicolumn{2}{|c|}{ Mantle } & \multicolumn{2}{|c|}{ Gills } \\
\hline & $w-Q P X$ & $\mathrm{u}-\mathrm{QPX}$ & w-QPX & $\mathrm{u}-\mathrm{QPX}$ & $w-Q P X$ & $\mathrm{u}-\mathrm{QPX}$ & w-QPX & $\mathrm{u}-\mathrm{QPX}$ & $w-Q P X$ & $\mathrm{u}-\mathrm{QPX}$ & $w-Q P X$ & $\mathrm{u}-\mathrm{QPX}$ \\
\hline hemocyte defensin & & & + & & & & & & & & & \\
\hline big defensin & & & & & & & & & & & +++ & \\
\hline lysozyme & & & & & + & & ++ & & & & + & --- \\
\hline $\mathrm{Clq}-\mathrm{TNF}$ related protein & & & + & & & & & & & & & \\
\hline TRAF- 6 & & & & & & & & & & & -- & \\
\hline Toll-like receptor & & & & & & & - & & & & & \\
\hline RACK-I & +++ & & & & +++ & +++ & & + & & + & ++ & +++ \\
\hline $\begin{array}{l}\text { peroxisome proliferator- } \\
\text { activated receptor }\end{array}$ & & & & & + & & & & & & & + \\
\hline HSP70 & & & - & & & + & & & & & & \\
\hline stress-induced protein STI & & & & & + & & & & & & & \\
\hline ferritin & & & - & & & & & & & & ++ & + \\
\hline metallothionein & & & & & & ++ & & & & & - & +++ \\
\hline actin & & & + & & ++ & & & & & & & \\
\hline$A P-1$ & & & & & ++ & & + & & & & ++ & \\
\hline elongation factor beta & +++ & & & & & & & & - & & --- & +++ \\
\hline NADH sub-unit IV & & & & & & & & + & & & & \\
\hline senescente associated protein & & & & & & & & & & & -- & + \\
\hline cytochrome P450 like TBP & +++ & & & & & & & & - & & & \\
\hline
\end{tabular}

Symbols + and - respectively indicate significant increase or decrease of gene expression compared to controls and the number of symbols for each condition refers to the $p$-value: + or $-: p<0.05,++$ or --: $p<0.01$ and +++ or ---: $p<0.001$.

[44] demonstrated that MT's were able to scavenge reactive oxygen species. In mammals, immune stimulants have been shown to be effective inducers of MT's [45]. However, the role of MT's in invertebrates, and especially in bivalves, appears more complex. Bacterial challenge induced a repression of MT expression in Crassostrea virginica [26] but not in the bay scallop Agropecten irradians [46] or during trematode parasitism in the cockle Cerastoderma edule where MT concentration increased [47]. Differences of MT expression could be related to the nature of the pathogen and its capacity to produce toxic compounds against its host. In our study, MT was significantly up-regulated in mantle after 28 days and gill tissues after 48 days in clams challenged by unwashed QPX but not in w-QPX challenged clams (Table 3). Discriminant analysis in mantle and gill tissues also revealed the specific importance of MT to separate the treatments in Function 1 (Table 6). Ferritin has also been classified as a stress protein due to its similarity with proteins involved in detoxification processes [24]. However, ferritin was also associated with defense mechanisms because of its role in the regulation of iron availability to infectious agents [48]. Previous studies demonstrated an increase of ferritin expression in invertebrates following exposures to patho-

Table 4: Effects of QPX challenge, sampling time and tissue type on gene expression in M. mercenaria (Multifactor ANOVA followed by Holm-Sidak post-hoc test).

\begin{tabular}{|c|c|c|c|c|c|c|c|}
\hline & Time & condition & tissue & time $\times$ condition & time $\times$ tissue & condition $\times$ tissue & time $\times$ condition $\times$ tissue \\
\hline hemocyte defensin & & & & & $*$ & & \\
\hline big defensin & $* * *$ & $*$ & $* *$ & $* *$ & $* * *$ & & $* *$ \\
\hline lysozyme & & & & $*$ & & & $*$ \\
\hline Toll-like receptor & $* * *$ & & $*$ & $*$ & $* * *$ & & $*$ \\
\hline ferritin & $* * *$ & & & & & & \\
\hline actin & $* *$ & $*$ & $* *$ & $* * *$ & $* *$ & $*$ & $* * *$ \\
\hline AP-I & $*$ & & & $*$ & $*$ & & $* *$ \\
\hline NADH sub-unit IV & $*$ & & & & $*$ & & \\
\hline senescente associated protein & $* * *$ & & $*$ & $*$ & $* * *$ & & \\
\hline
\end{tabular}

Only genes showing significant variations are presented. Symbols refer to the $p$-value: $*$ : $<<0.05, * *: p<0.01$ and $* * *: p<0.00$ I. 

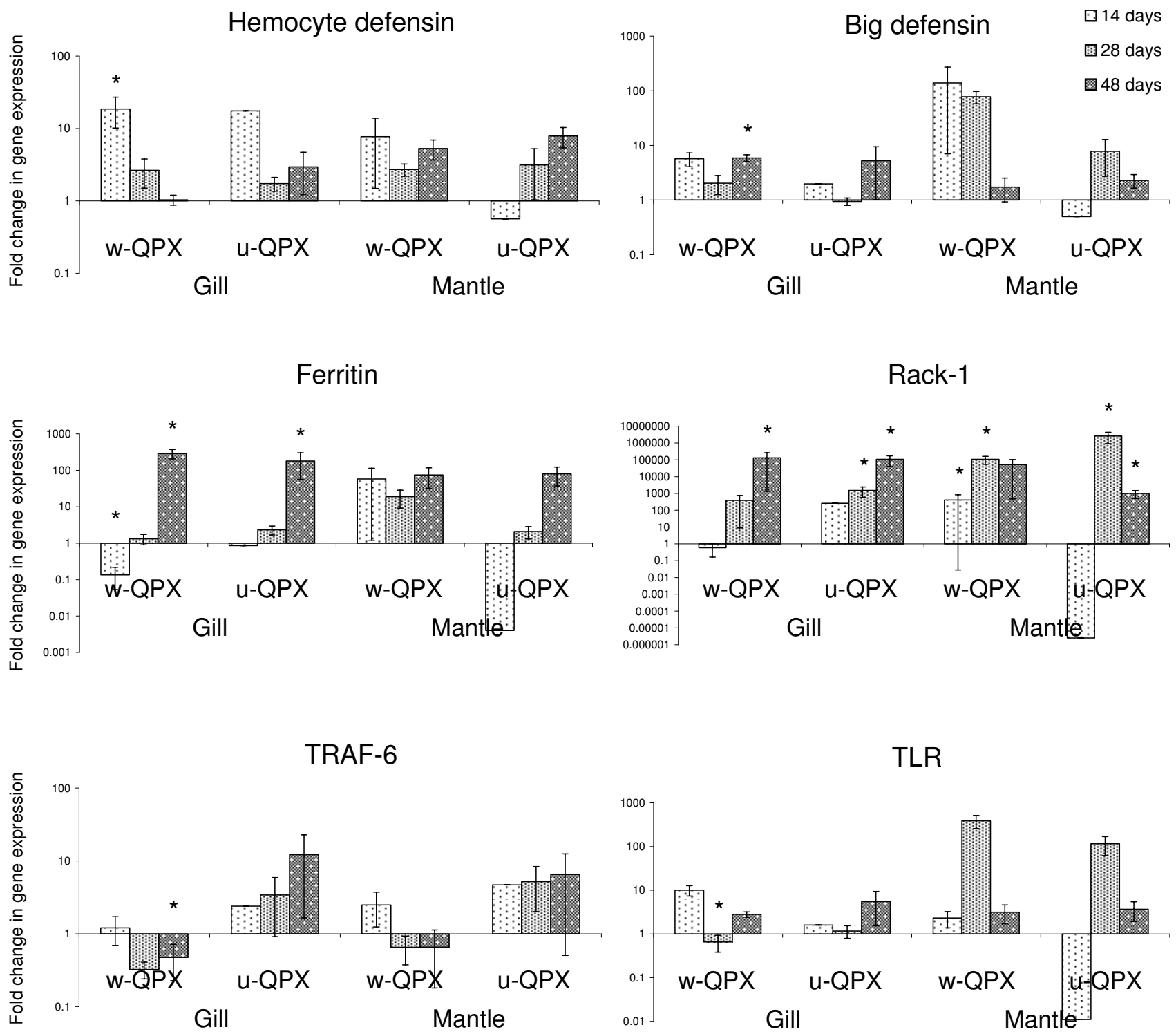

Figure 2

Relative expression by quantitative PCR of selected transcripts from SSH (hemocyte and big defensins, ferritin, RACK-I) and hemocyte (TRAF-6 and TLR) libraries. Expression levels were normalized to I8S RNA and presented as relative expression to controls (mean $\pm S D, n=8$ clams). * indicates significant differences of gene expression compared to controls at $p<0.05$ (Student's $t$-test).

gen-associated molecular patterns (PAMPs) or bacterial challenge $[24,49,50]$. In our study, quantitative PCR revealed an increase of ferritin expression in clams challenged by QPX after 28 and 48 days (Figure 2). However, significant increase of ferritin expression was only observed in gill tissues (Table 3). The biological significance of changes in ferritin expression levels is not known in clams since the effects of iron on QPX has never been investigated, but Gauthier and Vasta [51] demonstrated limited in vitro growth of the oyster pathogen Perkinsus marinus under low iron concentrations.

Subtracted libraries also allowed the identification of genes coding for several proteins involved in humoral defense including lysozyme, lectins and defensins. Lysozyme is a well-known protein possessing anti-microbial activities; lysozyme activity has been detected in the body fluids and tissues of many bivalve mollusks and is believed to play a role in host defense and digestion 
Table 5: Gene expression data from different sampling times were combined.

\begin{tabular}{|c|c|c|c|c|c|c|c|c|}
\hline Tissue & $\begin{array}{l}\text { Discriminant } \\
\text { function }\end{array}$ & Eigenvalue & $\begin{array}{c}\text { relative } \\
\text { percentage }\end{array}$ & $\begin{array}{c}\text { Canonical } \\
\text { Correlation }\end{array}$ & $\begin{array}{c}\text { Wilks } \\
\text { Lambda }\end{array}$ & $\begin{array}{l}\text { Chi- } \\
\text { Square }\end{array}$ & $\begin{array}{c}\text { Degrees of } \\
\text { freedom }\end{array}$ & $\begin{array}{l}\text { Statistical } \\
\text { significance }\end{array}$ \\
\hline \multirow[t]{2}{*}{ Mantle } & I & 1.18 & 68.3 & 0.74 & 0.30 & 50.4 & 36 & 0.05 \\
\hline & 2 & 0.55 & 31.7 & 0.59 & 0.65 & 18.1 & 17 & 0.38 \\
\hline \multirow[t]{2}{*}{ Gills } & I & I.54 & 81.5 & 0.78 & 0.29 & 57.2 & 36 & 0.01 \\
\hline & 2 & 0.35 & 18.5 & 0.51 & 0.74 & 13.9 & 17 & 0.67 \\
\hline
\end{tabular}

$[19,52,53]$. Different results have been previously reported on the variation of lysozyme concentration in response to parasites in mollusks. Lysozyme concentrations were unchanged in clams Tapes decussatus infected by Perkinsus atlanticus [54] and in oysters Crassostrea virginica infected by $P$. marinus $[55,56]$. However, a subsequent investigation in oysters showed a slight decrease in lysozyme concentration in $P$. marinus-infected oysters [57]. Our results indicate a differential response according to the treatment since the injection of washed QPX cells (w-QPX) induced significant expression of lysozyme in mantle and gill tissues, whereas unwashed parasite cells (u-QPX) caused a down-regulation of lysozyme expression in gill tissues after 48 days (Table 3 ).

Two different lectins were also identified in up-regulated libraries (Table 1). Lectins play an important role in invertebrate immunity as non-self pattern recognition molecules by promoting agglutination and opsonization of pathogens. In Manila clams Ruditapes philippinarum, Kang et al. [35] demonstrated significant increase in lectin expression following pathogen challenge. Interestingly, lectins isolated from $R$. philippinarum [58] and oysters $C$. virginica [59] bind to the surfaces of purified hypnospores from Perkinsus sp. enhancing their phagocytosis by hemocytes. Identified lectins in libraries could as well be associated to the activation of the complement pathway since a thioester-containing protein (TEP) was also found in subtracted libraries (Table 2). Complement pathway is activated in reaction to the presence of PAMPs, leading to increased opsonization and phagocytosis activity by defense cells [60]. Several TEP with homologies with $\alpha^{-}$ macroglobulin were previously characterized in other invertebrates $[61,62]$ and in bivalves $[63,64]$. A transcript with homologies with C1q was also present in our libraries. $\mathrm{C} 1 \mathrm{q}$ is the target recognition of the classical complement pathway that is crucial for the clearance of pathogens in vertebrates [65] and invertebrates [66].

Table 6: Structure matrix of Discriminant Analyses on gene expression data obtained from mantle and gill tissues.

\begin{tabular}{|c|c|c|c|c|}
\hline & \multicolumn{2}{|l|}{ mantle tissue } & \multicolumn{2}{|l|}{ gill tissue } \\
\hline & function & function & function & function \\
\hline & 1 & 2 & 1 & 2 \\
\hline Toll-like receptor & $1.118^{*}$ & 1.021 & $2.109 *$ & -1.269 \\
\hline AP-I & $4.635^{*}$ & 0.899 & $1.492 *$ & -0.098 \\
\hline peroxisome proliferator-activated receptor & $-0.356^{*}$ & 0.119 & $-2.77 I^{*}$ & 1.871 \\
\hline big defensin & $-1.164^{*}$ & -0.197 & $2.178^{*}$ & -0.883 \\
\hline lysozyme & $-2.662 *$ & 0.220 & $-0.704 *$ & 0.163 \\
\hline metallothionein & $6.612^{*}$ & -2.521 & $0.313 *$ & 0.241 \\
\hline Actin & $-2.452^{*}$ & -1.006 & $-2.161 *$ & 1.222 \\
\hline NADH sub-unit IV & $0.335^{*}$ & 0.073 & $-1.133 *$ & 1.051 \\
\hline senescence associated protein & $-0.095^{*}$ & 0.036 & $0.352 *$ & 0.025 \\
\hline hemocyte defensin & $1.642 *$ & 0.238 & 0.461 & 0.775 \\
\hline HSP70 & $1.413^{*}$ & -0.295 & 0.377 & -0.613 \\
\hline elongation factor beta & $-6.159 *$ & -0.112 & -2.472 & 2.639 \\
\hline cytochrome P450 like TBP & -0.155 & -0.270 & $-0.107 *$ & -0.009 \\
\hline TRAF 6 & 0.322 & -0.364 & $-1.859 *$ & -0.946 \\
\hline stress-induced protein STI & -1.698 & 2.122 & $5.207^{*}$ & -3.063 \\
\hline RACK-I & 0.1242 & -0.645 & 0.033 & 0.181 \\
\hline $\mathrm{Clq}-\mathrm{TNF}$ related protein & 0.278 & 0.857 & 0.142 & -0.559 \\
\hline Ferritin & 0.115 & 0.139 & -0.430 & 0.992 \\
\hline
\end{tabular}

Largest absolute correlations between variables and discriminant functions are indicated by *. 
Table 7: Pearson's correlation coefficients of genes related to cell signalling (AP-I, TLR, TRAF-6; RACK-I) and humoral defense factors (hemocyte and big defensins, lysozyme).

\begin{tabular}{|c|c|c|c|}
\hline & lysozyme & big defensin & hemocyte defensin \\
\hline \multirow[t]{2}{*}{ AP-I } & 0.934 & 0.736 & -0.025 \\
\hline & $\left(5.3 e^{-51}\right)$ & $\left(-2.5 e^{-20}\right)$ & (NS) \\
\hline \multirow[t]{2}{*}{ Toll-like receptor } & 0.408 & 0.726 & -0.030 \\
\hline & $\left(7.9 e^{-6}\right)$ & $\left(1.4 e^{-19}\right)$ & (NS) \\
\hline \multirow[t]{2}{*}{ TRAF 6} & -0.034 & 0.016 & 0.087 \\
\hline & (NS) & (NS) & (NS) \\
\hline \multirow{2}{*}{ RACK-I } & -0.015 & -0.039 & -0.020 \\
\hline & (NS) & (NS) & (NS) \\
\hline
\end{tabular}

$P$-values are indicated between parentheses and non significant correlations are indicated by NS.

Our approach also led to the identification of two different defensins that show different expression patterns in mantle and gill tissues. Defensins are small antimicrobial peptides (AMP) and represent major actors in innate immunity [67]. Defensins were isolated from mussels [68], scallops [33] and oysters [69,70]. These AMPs can be constitutively expressed, as observed in oysters [70], or induced in response to infection, as in scallop [33]. Most previously described defensins were characterized from hemocytes but some were also constitutively expressed in pallial tissues [69]. In our study, quantitative PCR revealed that the hemocyte defensin was significantly upregulated in gills only after 14 days, while no significant change was observed in mantle, despite the tendency to an increase of the hemocyte defensin expression after 48 days following challenge with washed and unwashed QPX cells (Figure 2). Initial induction of the hemocyte defensin after 14 days in gills could reflect systemic hemocyte activity as gill tissues are normally rich in hemocytes compared to mantle. Later on, increased PCR signals in mantle tissues could be related to increased expression in hemocytes present near infection sites or might simply reflect the mobilization of hemocytes toward active infection sites as part of the normal inflammatory response $[5,8]$. This may, in turn, lead to the observed shift of gene expression among tissues. Similar patterns were found in other studies investigating defensin expression in oysters [70]. Regarding the big defensin, a significant induction was observed after 48 days in gill tissues of clams challenged with washed QPX whereas a tendency to a decrease of defensin expression was noticeable in mantle tissue (Figure 2). Moreover, the big defensin appeared as an important variable to discriminate treatments in gill and mantle tissues (Table 6). Defensins present a great diversity in terms of structural features, biological properties and functions, and also in their tissue distribution and expression. Defensins from C. gigas exhibit high activities against gram positive bacteria but low activity against fungi [69], whereas big defensins from A. irradians and the horseshoe crab Tachypleus tridentatus exhibit strong fungicidal activities $[33,71]$. Trends of both defensins suggest a certain level of specificity in the response of $M$. mercenaria to washed and unwashed QPX cells in mantle and gill tissues.

Several genes corresponding to membrane receptors and elements of pathways involved in defense responses have also been identified in our libraries. Among them, RACK1 is involved in the protein kinase C (PKC) pathways and acts as an activator/receptor for this protein [72]. RACK-1 plays a key role as the crossroad among several cellular pathways in cell communication by acting as a scaffold protein on the translocation of the signalling proteins towards the membrane-bound receptors [72]. Ron et al. [73] demonstrated in situ association of RACK-1 and PKC during phorbol 12-myristate 13-acetate (PMA) challenge, an activator of reactive oxygen species production $[74,75]$. Overexpression of RACK- 1 also led to enhanced spreading and increased focal adhesion in mammalian cells [76]. These results suggested an involvement of RACK-1 in phagocytosis and ROS production. RACK-1 was previously identified in bivalves exposed to pollutants, physical stress and pathogens $[36,41,77]$. In the hard clam, our quantitative PCR results revealed that QPX challenge significantly induced the expression of RACK-1 in both gill and mantle tissues (Figure 2 and Table 3 ). Libraries generated from hemocytes also led to the identification of several elements of the NF-kB pathway. Toll-like receptors (TLRs) are among the most important families of pattern recognition receptors (PRRs) and have already been identified in other bivalves $[25,30]$. They are able to selectively recognize and initiate the response against a large number of varied and complex PAMPs [78]. Tumor necrosis factor receptor-associated factor (TRAF), another component of the NF-kB pathway, was also detected in our hemocyte libraries. This intermediary possesses a unique receptorbinding specificity that results in its crucial role as the signalling mediator for both the TNF receptor superfamily and the TLR superfamily [79]. Activation of this pathway induces expression of immune response genes triggered by transcriptional activator proteins. Among them, the transcriptional factor AP-1 was identified in our subtracted libraries. Interestingly, our results demonstrated an important involvement of NF-kB components in the differential response to washed and unwashed parasite cells (Tables 4 and 6), as well as a high correlation ( $p<$ 0.001 ) between humoral defenses (lysozyme, big defensins), TLR and the transcriptional factor AP-1 (Table 7 ). These results suggest that activation of the NF-kB pathway occurred following the recognition of QPX by TLR and the activation of AP-1, leading to a specific response characterized by the production of humoral defense factors including lysozyme and the big defensin. 

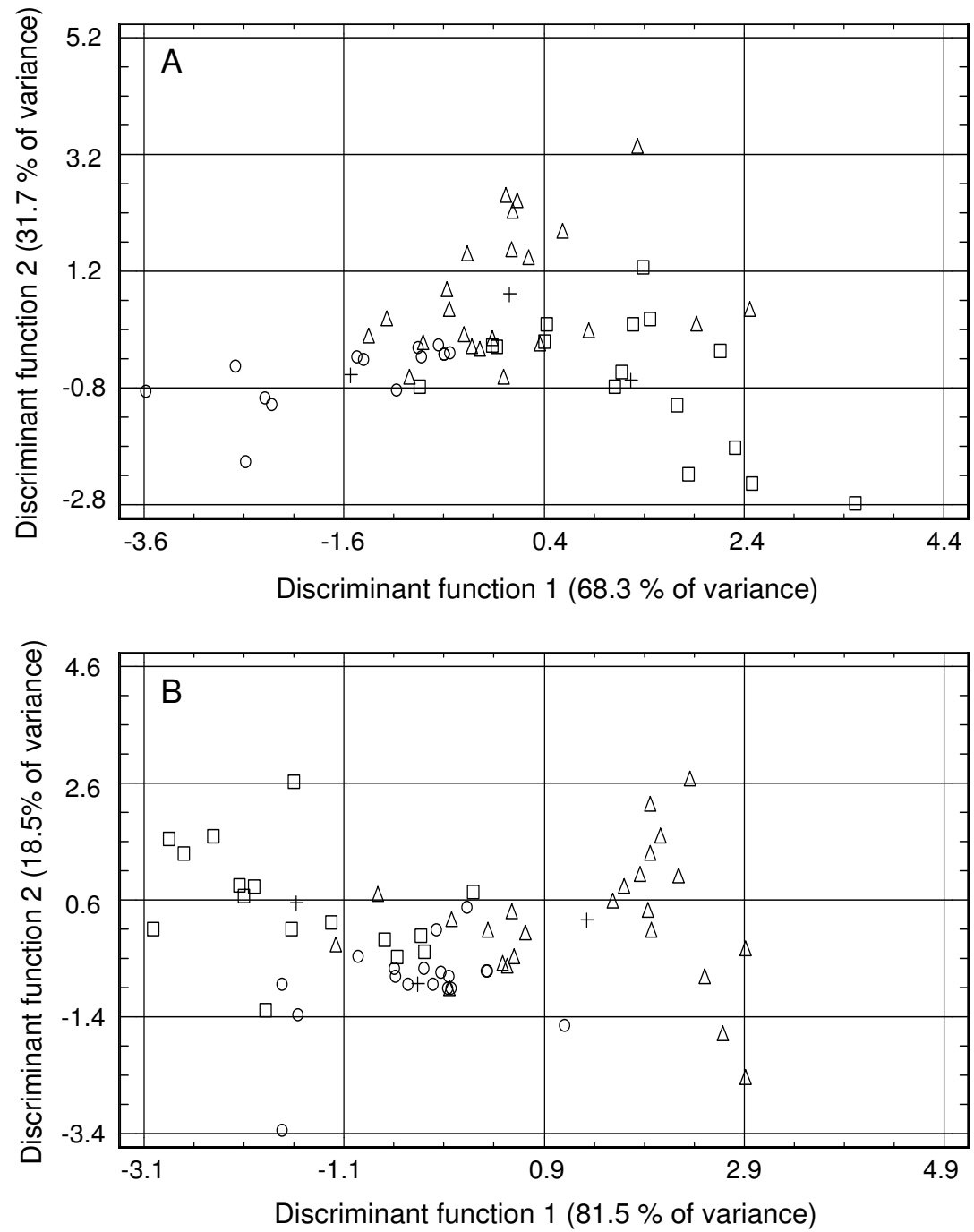

Figure 3

Scatter plots of Discriminant Analysis scores in mantle (A) and gill (B) tissues for un-challenged controls (circles) and clams challenged with washed (triangles) or unwashed (squares) QPX cells. Positions of group centroids for each treatment are indicated by a black cross.

Actin is often used as a house-keeping gene but we clearly observed a modulation of this gene in gills (14 days) and mantle (28 days) tissues following challenge with washed parasite cells (Tables 3, 4 and 6). Actins are highly conserved proteins that are ubiquitously expressed in all eukaryotic cells. They are involved in the formation of filaments that are major components of the cytoskeleton and participate in many important cellular functions including cell motility, organelle movements and cell signalling $[80,81]$. With regard to infections, actin was, upregulated in Biomphalaria tenagophila at a proteomic level in the presence of Schistosoma mansoni [82]. The involvement of actin in QPX disease pathogenesis, if any, is unclear but it may participate in the encapsulation of par- asite cells by host hemocytes leading to healing as in other host-parasite models [83].

Results of quantitative PCR also indicated that some genes were differentially regulated according to analyzed tissue (TLR, big defensin, Table 4) or inoculum (big defensin, Tables 4 and 6). Discriminant Analysis revealed the importance of signalling pathways and humoral defenses to differentiate between QPX-challenged and unchallenged clams or between clams injected with washed or unwashed parasite cells (Figure 3 and Table 6). It should be mentioned that, because of sample size requirements of the statistical test, Discriminant Analyses were performed on data obtained throughout the experiment by 
pooling samples collected at 14,28 and 48 days post-challenge. Such a holistic approach eliminated the effect of genes that displayed high temporary modulations within each treatment and might neglect certain specific clam responses. This limitation could explain the barely significant results obtained with Discriminant Analyses in mantle tissues (Table 5). Despite this drawback, our analyses discriminated between clams injected with washed or unwashed parasite cells, highlighting the importance of QPX mucus during host-pathogen interactions. QPX mucus was suggested to represent a virulence factor that protects the parasite from host's cellular and humoral defense mechanisms [5]. Proteases were also detected in QPX mucus [84] and Thrautochytrids are known to produce several proteolytic enzymes as extracellular products [85]. Injection of unwashed QPX could protect the parasite from constitutive defenses of hard clams and enhance their ability to establish infection within host tissues, as well as prevent the detection of the parasite's PAMP's, thereby limiting the response of hard clams. In contrast, washed cells can be more readily phagocyted or encapsulated by hemocytes and neutralized by humoral factors [23]; they can also present PAMPs on their surface, enhancing clam's immune response. Thus, injection of washed QPX cells could induce an efficient defense response in clams, leading to elimination of parasites and failure of disease establishment.

\section{Conclusion}

In conclusion, this study is the first to characterize molecular modulation in clams in response to QPX infection. A large number of new candidate genes was identified including several genes involved in stress and defense response and cell signalling. Quantitative PCR revealed significant changes in the expression of some of these genes in response to QPX challenge, as well as some correlation between gene expression of intermediates of signalling pathway and humoral defenses. Additional experiments are needed to further characterize molecular components involved in M. mercenaria response to its parasite. Specifically, further experiments should compare gene expression in susceptible and resistant clam broodstocks. Generated sequence information could also contribute to the construction of the first hard clam microarray necessary for investigating gene expression on a larger scale.

\section{Methods QPX cultures}

QPX strain NY0313808BC7 was isolated from nodules of infected New York clams [86] and subcultured in a culture medium based on muscle homogenates from hard clams adjusted at $1000 \mu \mathrm{g} . \mathrm{mL}^{-1}$ of proteins in filter-sterilized artificial seawater (FASW) [87]. QPX cultures were initiated in $25-\mathrm{cm}^{2}$ flasks incubated at $23^{\circ} \mathrm{C}$ for 1 week to reach the exponential phase of growth. Parasite cultures were thereafter subdivided into two aliquots: one aliquot was untreated resulting in QPX cells associated with their typical abundant mucus secretions surrounding parasite cells (cells and mucus - u-QPX) and another aliquot was washed according to a protocol adapted from Anderson et al. [23] to remove the mucus from cells (w-QPX). Briefly, a volume of QPX culture was mixed well by repeatedly drawing up and expelling the culture with a $3 \mathrm{~mL}$-syringe without a needle. A small volume of well-mixed culture was then suspended in five times its volume of sterile culture medium. This suspension was then vortexed for 1015 seconds and centrifuged for $15 \mathrm{~min}$ at $600 \times \mathrm{g}$ [23]. The supernatant was removed and the QPX pellet was then washed two times and resuspended in sterile culture medium. This washing procedure has been thoroughly tested and found not to affect QPX viability [88]. QPX biomass in each aliquot was then measured using a semiautomated fluorometric technique according to Buggé and Allam [88] and QPX suspensions were adjusted with sterile culture medium to obtain the same parasite biomass.

\section{Hard clams and experimental infections}

QPX-free adult Mercenaria mercenaria were obtained from Frank M. Flowers Oyster Company (Oyster Bay, NY). Clams were acclimated one week in the laboratory, held in 150-L tanks with re-circulating water (28-30 ppt) at 21 $\pm 1^{\circ} \mathrm{C}$ and fed daily with commercial algae (DT's Live Phytoplankton, Sycamore, IL). After acclimation, clams were divided into three groups of 30 individuals and challenged with either washed (w-QPX) or unwashed (uQPX) parasite cells to compare clam response in presence or absence of the mucus layer surrounding QPX cells. Experimental infections were performed according to Dahl and Allam [22] by injecting $100 \mu \mathrm{L}$ of culture medium containing $5 \times 10^{4} \mathrm{QPX}$ cells into clam's pericardial cavity. Control clams were injected with $100 \mu \mathrm{L}$ of sterile culture medium. Following injection, clams were maintained out of the water for $1.5 \mathrm{~h}$ and were thereafter transferred to separate tanks. Mortality was monitored daily. For each experimental condition, 8 clams were sampled at 14, 28 and 48 days after challenge. Hemolymph was withdrawn from the adductor muscle and held individually on ice. Samples were centrifuged at $700 \times \mathrm{g}$ for 10 min at $4^{\circ} \mathrm{C}$, plasma was discarded and hemocyte pellets were rapidly frozen in liquid nitrogen before storage at $80^{\circ} \mathrm{C}$. Concomitantly, gill and mantle tissues were dissected and frozen individually until RNA extraction.

\section{RNA extraction}

Total RNA was extracted from hemocyte pellets and clam tissues using TRI ${ }^{\circledast}$ Reagent (Invitrogen, Carlsbad, CA, USA). Polyadenylated RNA was isolated using the PolyATtract ${ }^{\top} \mathrm{mRNA}$ Isolation System (Promega, Madison, WI, 
USA) according to manufacturer's instructions. Messenger RNAs were resuspended in RNase-free water and both quantity and quality were assessed by spectrophotometry (OD260, OD280).

\section{Suppression subtractive hybridization}

The suppression subtractive hybridization technique (SSH) [89] was used to identify genes involved in clam's immune response following QPX challenge. Messenger RNAs isolated from gill and mantle tissues at 14 and 48 days were pooled for each treatment and sampling time. Both forward and reverse subtracted libraries were generated on $2 \mu \mathrm{g}$ of pooled mRNA for each SSH library construction (Figure 4). First and second strand cDNA synthesis, RsaI endonuclease enzyme digestion, adapter ligation, hybridization, and PCR amplification were performed as described in the PCR-select cDNA subtraction manual (Clontech, Palo Alto, CA, USA). Differentially expressed PCR products were purified and cloned into pGEM-T vector (Promega, Madison, WI, USA). Bacteria (DH5 $\alpha$ phage resistant) were transformed and cultured in Luria-Bertani medium (with $100 \mu \mathrm{g} . \mathrm{L}^{-1}$ ampicillin, final concentration). Vectors from two hundred colonies per library were extracted using an alkaline lysis plasmid minipreparation, and screened by size after digestion. A total of 298 clones from forward and reverse libraries were sequenced using an AB3100 sequencer (Perkins-Elmer) and Big Dye Terminator V3.1 Kit (Perkins-Elmer).

\section{Full-length cDNA library construction}

Messenger RNAs isolated from hemocytes were pooled and cDNA library was generated using Creator ${ }^{\mathrm{TM}}$ SMART $^{\mathrm{TM}}$ cDNA Library Construction Kit (Clontech, Palo Alto, CA, USA) according to manufacturer's instructions. The cDNA library was cloned into the pDNR-LIB Vector and transformed in bacteria (DH5 $\alpha$ phage resistant) and cultured in Luria-Bertani medium (with $100 \mu \mathrm{g} \cdot \mathrm{L}^{-1}$ ampicillin, final concentration). A total of 1352 clones were randomly selected and sequenced using an AB3100 sequencer (Perkins-Elmer) and Big Dye Terminator V3.1 Kit (PerkinsElmer).

\section{Sequence analysis}

The ABI sequence data were basecalled using 'phred' http:/ /www.phrap.org and subsequently clipped for bad-quality and vector using 'lucy' (compbio.dfci.harvard.edu/tgi/ software) with standard parameters. cDNA sequences were automatically screened against UniProt (BLASTX) and all ESTs from EMBL (BLASTN).

\section{Real-Time PCR Analyses}

Fourteen genes were selected from SSH libraries for further investigations of their expression including 3 stress-

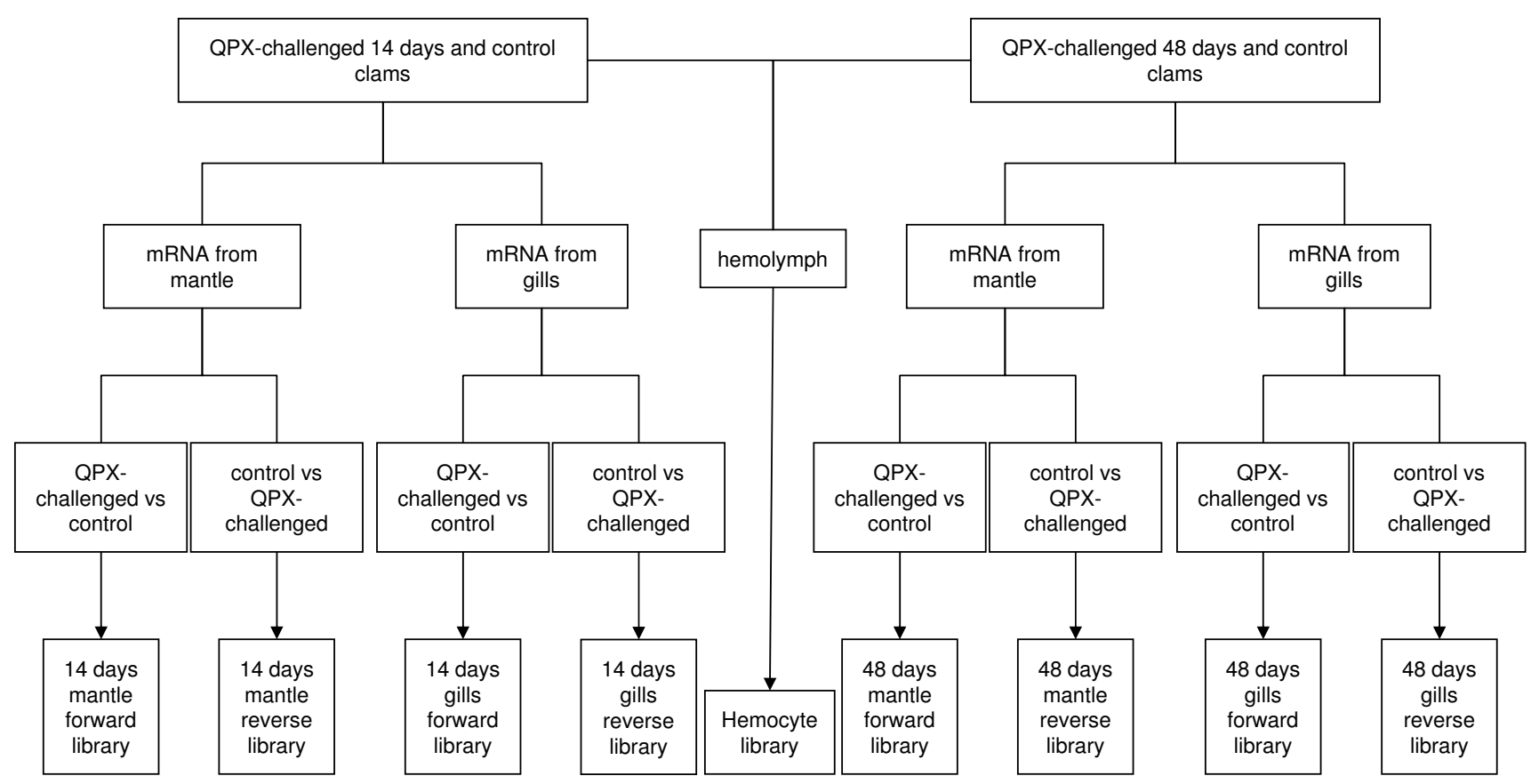

Figure 4

Diagram of the different subtractions and cDNA libraries performed in $\boldsymbol{M}$. mercenaria. Clams challenged with washed and unwashed QPX cells were pooled to perform SSH. The hemocyte library was generated from a pool of all challenged and unchallenged clams collected at 14 and 48 days. 
related genes (metallothionein, HSP 70 and ferritin), 3 defense-related genes (big defensin, hemocyte defensin and lysozyme) and 2 genes involved in cell signalling (receptor of activated kinase $\mathrm{C} 1$, peroxisome proliferatoractivated receptor). In addition, several transcripts involved in gene regulation, transcription factors, the cytoskeleton and metabolism were analyzed (elongation factor 1 beta, transcription factor AP-1, actin, NADH4). Two transcripts (senescence-associated protein, cytochrome P450 like TBP) previously identified in other bivalves during parasite challenges [25] and in our libraries were also selected. Four additional transcripts encoding for stress related gene (stress-induced protein - STI1) and components of the NF-kB pathway (tumor necrosis factor receptor-associated factor - TRAF-6, Toll like receptor - TLR) and complement system (C1q-TNF related protein) were selected from the hemocyte library. Expression of all candidates was compared to controls in gill and mantle tissues at 14, 28 and 48 days post-challenge. For each sample, $10 \mu \mathrm{g}$ total RNA was individually submitted to reverse transcription using the oligo $\mathrm{dT}$ anchor primer (5'-GACCACGCGTATCGATGTCGACT ${ }_{(16)} \mathrm{V}-3$ ') and Moloney murine leukaemia virus (M-MLV) reverse transcriptase (Promega, Madison, WI, USA). The real-time PCR assay was performed with $3 \mu \mathrm{L}$ cDNA ( $1 / 20$ dilution) in a total volume of $10 \mu \mathrm{L}$, using a Chromo $4^{\mathrm{TM}}$ System QPCR (Bio-Rad, Hercules, CA USA). Concentrations of the reaction components were as follows: $1 \times$ Absolute QPCR SYBR Green ROX Mix (ABgene, UK) and $70 \mathrm{nM}$ of each primer. Primer sequences of the 18 genes selected in the M. mercenaria SSH and hemocyte libraries are presented in Table 8. Reactions were realized with activation of Thermo-Start ${ }^{\oplus}$ DNA polymerase at $95^{\circ} \mathrm{C}$ for $15 \mathrm{~min}$ followed by amplification of the target cDNA ( 50 cycles of

Table 8: Combinations of primers used in quantitative PCR assays.

\begin{tabular}{|c|c|c|}
\hline Gene name & Gene function & Primer sequences \\
\hline \multirow[t]{2}{*}{$18 \mathrm{~S}$} & Ribosomal protein & F: CTGGTTAATTCCGATAACGAACGAGACTCTA \\
\hline & & R: TGCTCAATCTCGTGTGGCTAAACGCCACTTG \\
\hline \multirow[t]{2}{*}{ Hemocyte defensin } & Immune system & F: ACAAATGTAACAGGCATTGTAGGAGCAT \\
\hline & & R: CATGTGCATCTTCGGTAAAAAGTCCA \\
\hline \multirow[t]{2}{*}{ Big defensin } & Immune system & F: ATGGACACTAGGAAAGTCTACTGTGTGCT \\
\hline & & R: ACAAGTGCAACCCAGACCCAAGGTGA \\
\hline \multirow[t]{2}{*}{ Lysozyme } & Immune system & F: ATAACGAAAGACCAAGCTCGTGCTCT \\
\hline & & R: GTTTTGGGTCCTAGATCTCCCCTGTA \\
\hline \multirow[t]{2}{*}{$\mathrm{CIq}-\mathrm{TNF}$ related protein } & Immune system & F: ATGCAAGTCAGTGCCGTGATACACCCAGA \\
\hline & & R: AATAAAGCGCCACTGAAAGTTGTTCCATG \\
\hline \multirow[t]{2}{*}{ TRAF-6 } & Immune system & F: GAACTAGCAAACAGGAATTGGGAGGCGCT \\
\hline & & R:GTCAAGTGATGGCTCATCTTGGATGCTGC \\
\hline \multirow[t]{2}{*}{ Toll-like receptor } & Immune system & F: GTAACAAATTTCACTCTGGCCGCTGACGC \\
\hline & & R: TAGCTGAAATCCAACGACTGCACCCGTAA \\
\hline \multirow[t]{2}{*}{ RACK-I } & Cell communication & F: CCTAACAGATACTGGCTGTGTGCTGC \\
\hline & & R: GTCTGTCCATCTGCGGACCATGCAAG \\
\hline \multirow[t]{2}{*}{ Peroxisome proliferator-activated receptor } & Cell communication & F: CATAGCCAATTCCATACCCCTGGCCA \\
\hline & & R: AGTTGGCATCGCCACTGTCGCTGCTC \\
\hline \multirow[t]{2}{*}{ HSP70 } & Stress response & F: AATGACAAAGGCCGTCTCAGCAAGGA \\
\hline & & R: TCTAACCAACTGATGACCTCGCTACA \\
\hline \multirow{2}{*}{ Stress-induced protein STI } & Stress response & F: GAAGCTGTTGAACAAGCCAAGAGTGGAGC \\
\hline & & R: GTCTCTTGAATTCGGGGATCTTGAGCTGC \\
\hline \multirow[t]{2}{*}{ Ferritin } & Iron transport & F: ATGTCTGTTTCACGACCTCGACAGAA \\
\hline & & R: AGTTTCTCGGCATGCTCACGTTCCTC \\
\hline \multirow[t]{2}{*}{ Metallothionein } & Detoxification & F: ACCAGTGATGGTGGCTGCAGGTGTGG \\
\hline & & R: TTACACGAACAGCCACTATCACACTG \\
\hline \multirow[t]{2}{*}{ Actin } & Cytoskeleton & F: ATTGTGATGGACTCTGGTGATGGTGT \\
\hline & & R: TCTCTAACAATTTCTCTCTCAGCCGTTGT \\
\hline \multirow[t]{2}{*}{ Transcription factor AP-I } & Transcription & F: AGAAAACTTGAAAGAATTGCGCGACT \\
\hline & & R: TGTGACATCATTATCTGGCACCCACT \\
\hline \multirow[t]{2}{*}{ Elongation factor beta } & Transcription & F: CCTTGGGATGATGAAACAGATATGGC \\
\hline & & R: CTAATCTTGGCATCTTCTATAACAGC \\
\hline \multirow[t]{2}{*}{ NADH sub-unit IV } & Mitochondrial respiration & F: CCGTGGGATTTAGGGAGGGATAATATGCT \\
\hline & & R: ACTCCAGTTAACAACATTGATCCССTCAA \\
\hline \multirow{2}{*}{ Senescence associated protein } & unknown & F: AACCTGTCTCACGACGGTCTAAGCCCAGC \\
\hline & & R: TTACCACAGGGATAACTGGCTTGTGG \\
\hline \multirow[t]{2}{*}{ Cytochrome P450 like TBP } & unknown & F: GTCTGGAAAACGGCCACAAGGCACCT \\
\hline & & R: TTATACAAGGTAACCGGCTTGGACGC \\
\hline
\end{tabular}


denaturation at $95^{\circ} \mathrm{C}$ for $30 \mathrm{sec}$, annealing and extension at $60^{\circ} \mathrm{C}$ for $1 \mathrm{~min}$ ) and a melting curve program from 95 to $70^{\circ} \mathrm{C}$ that decreased the temperature by $0.5^{\circ} \mathrm{C}$ every 10 sec. Readings were taken at $60^{\circ} \mathrm{C}$. PCR efficiency (E) was determined for each primer pair by determining the slope of standard curves obtained from serial dilution analysis of cDNA from different experimental samples (treatment and control). The comparative CT method (2- $\Delta \Delta \mathrm{CT}$ method) was used to determine the expression level of analyzed genes [90]. The expression of the candidate genes was normalized using ribosomal RNA $18 \mathrm{~S}$ fragment as a housekeeping gene by the specific primers (Table 8). Fold units were calculated on normalized expression values by dividing gene expression in tissues from challenged clams by controls. Results are given as the mean and standard deviation of eight replicates per condition.

\section{Statistical analysis}

Variations in gene expression levels in tissues from clams submitted to different treatments were analyzed using Student's $t$-test using SigmaStat Version 3.10 (Systat Software, Inc). Effects of sampling times, treatments and tissues on gene expression were analyzed using multifactor analysis of variance (ANOVA) followed by a Holm-Sidak post-hoc test when appropriate. Correlation analyses of the expression of different genes were made using Pearson's method. Finally, Discriminant Analysis (DA) of gene expression was performed using Statgraphics plus Version 2.1. As DA requires a minimum within-treatment sample size of 20, data from the different sampling times within each treatment were combined and DA was separately applied on mantle and gill tissue groups. DA determines linear combinations of variables (genes) that maximize differences among a priori defined groups (treatments). The relative contribution of each variable was assessed on the basis of the structure correlations to interpret the discriminating power of the independent variables. In all tests, differences were considered statistically significant at $p<0.05$.

\section{Authors' contributions}

MP carried out SSH and expression libraries, participated in the sequence alignment and drafted the manuscript. AT was in charge of molecular experiments, carried out real time PCR and helped in drafting the methodology section of the manuscript. BA is the lead PI on this work. He conceived the design of the study, coordinated experiments and supervised the statistical analysis of the results. All authors read and approved the final manuscript.

\section{Acknowledgements}

We thank Sabrina Rousseau for her help during this study, Dave Relyea for providing experimental clams and Dorothy Tsang for reviewing the manuscript. This research was partially supported by the NSF (project EF042905 I to BA) and is a resulting product from projects R/FBM-33 and R/XG-19 (to BA), funded under award NA07OAR4170010 from the
National Sea Grant College Program of NOAA to the Research Foundation of State University of New York on behalf of New York Sea Grant. Partial support to this study was also provided by the New York State Department of Environmental Conservation. The statements, findings, conclusions,

views and recommendations are those of the authors and do not necessarily reflect the views of any of those organizations.

\section{References}

I. Ford SE: Pests, parasites, diseases and defense mechanisms of the hard clam, Mercenaria mercenaria. In Biology of the hard clam Edited by: Kraeuter JN, Castagna M. Elsevier Science; Amsterdam; 200I:59I-628.

2. Stokes NA, Calvo LMR, Reece KS, Burreson EM: Molecular diagnostics, field validation, and phylogenetic analysis of Quahog Parasite Unknown (QPX), a pathogen of the hard clam Mercenaria mercenaria. Dis Aquat Org 2002, 52:233-247.

3. Bower SM: Labyrinthuloides haliotidis n-sp. (Protozoa, Labyrinthomorpha), a pathogenic parasite of small juvenile abalone in a British-Columbia mariculture facility. Can J Zool 1987, 65:1996-2007.

4. Whyte SK, Cawthorn RJ, McGladdery SE: QPX (Quahaug Parasite $X)$, a pathogen of northern quahaug Mercenaria mercenaria from the gulf of St Lawrence, Canada. Dis Aquat Org 1994, 19:129-136.

5. Smolowitz R, Leavitt D, Perkins F: Observations of a protistan disease similar to QPX in Mercenaria mercenaria (hard clams) from the coast of Massachusetts. J Invertebr Pathol 1998 , 7I:9-25.

6. Calvo LMR, Walker JG, Burreson EM: Prevalence and distribution of QPX, Quahog Parasite Unknown, in hard clams Mercenaria mercenaria in Virginia, USA. Dis Aquat Org 1998, 33:209-219.

7. Ford SE, Kraeuter JN, Barber RD, Mathis G: Aquaculture-associated factors in QPX disease of hard clams: density and seed source. Aquaculture 2002, 208:23-38.

8. Dove ADM, Bowser PR, Cerrato RM: Histological analysis of an outbreak of QPX disease in wild hard clams Mercenaria mercenaria in New York. J Aquat Anim Health 2004, 16:246-250.

9. Dahl S, Perrigault M, Allam B: Laboratory transmission studies of QPX disease in the hard clam: Interactions between different host strains and pathogen isolates. Aquaculture 2008, 280:64-70.

10. Calvo LMR, Ford SE, Kraeuter JN, Leavitt DF, Smolowitz R, Burreson $E M$ : Influence of host genetic origin and geographic location on QPX disease in Northern quahogs (= hard clams), Mercenaria mercenaria. J Shellfish Res 2007, 26:109-II9.

II. Bushek D, Allen SK: Host-parasite interactions among broadly distributed populations of the eastern oyster Crassostrea virginica and the protozoan Perkinsus marinus. Mar Ecol Prog Ser 1996, I39:|27-|4|.

12. Culloty SC, Cronin MA, Mulcahy MF: Potential resistance of a number of populations of the oyster Ostrea edulis to the parasite Bonamia ostreae. Aquaculture 2004, 237:4I-58.

13. Gaffney PM, Bushek D: Genetic aspects of disease resistance in oysters. J Shellfish Res 1996, 15:135-140.

14. Cheng TC, Bui MN, Howland KH, Schoenberg DA, Sullivan JT: Effect of pre-injection of Crassostrea virginica with bacteria on subsequent chemotactic response by its hemocytes. J Invertebr Pathol 1981, 38:122-126.

15. Pipe RK: Generation of reactive oxygen metabolites by the hemocytes of the mussel Mytilus edulis. Dev Comp Immunol 1992, 16: III-122.

16. Anderson RS: Hemocyte-derived reactive oxygen intermediate production in 4 bivalve mollusks. Dev Comp Immunol 1994, 18:89-96.

17. Chu FLE: Humoral defense factors in marine bivalves. Am Fish Soc Spec Publi 1988, 18:178-188.

18. Cheng TC: Selective induction of release of hydrolases from Crassostrea virginica hemocytes by certain bacteria. J Invertebr Pathol 1992, 59:197-200.

19. Allam B, Paillard C, Auffret M: Alterations in hemolymph and extrapallial fluid parameters in the Manila clam, Ruditapes philippinarum, challenged with the pathogen Vibrio tapetis. J Invertebr Pathol 2000, 76:63-69. 
20. Allam B, Paillard C, Howard A, Le Pennec M: Isolation of the pathogen Vibrio tapetis and defense parameters in brown ring diseased Manila clams Ruditapes philippinarum cultivated in England. Dis Aquat Organ 2000, 4I: 105-I I 3.

21. Paillard C, Allam B, Oubella R: Effect of temperature on defense parameters in Manila clam Ruditapes philippinarum challenged with Vibrio tapetis. Dis Aquat Organ 2004, 59:249-262.

22. Dahl SF, Allam B: Laboratory transmission studies of QPX disease in the northern quahog (= hard clam): Development of an infection procedure. J Shellfish Res 2007, 26:383-389.

23. Anderson RS, Kraus BS, McGladdery S, Smolowitz R: QPX, a pathogen of quahogs (hard clams), employs mucoid secretions to resist host antimicrobial agents. J Shellfish Res 2003, 22:205-208.

24. Gueguen Y, Cadoret JP, Flament D, Barreau-Roumiguiere C, Girardot AL, Garnier J, Hoareau A, Bachere E, Escoubas JM: Immune gene discovery by expressed sequence tags generated from hemocytes of the bacteria-challenged oyster, Crassostrea gigas. Gene 2003, 303:139-145.

25. Tanguy A, Guo XM, Ford SE: Discovery of genes expressed in response to Perkinsus marinus challenge in Eastern (Crassostrea virginica) and Pacific (C. gigas) oysters. Gene 2004, 338: $|2|-|3|$.

26. Jenny MJ, Warr GW, Ringwood AH, Baltzegar DA, Chapman RW: Regulation of metallothionein genes in the American oyster (Crassostrea virginica): Ontogeny and differential expression in response to different stressors. Gene 2006, 379: I56-I65.

27. Montagnani C, Labreuche Y, Escoubas JM: Cg-I kappa B, a new member of the I kappa B protein family characterized in the pacific oyster Crassostrea gigas. Dev Comp Immunol 2008, 32:182-190.

28. Yamaura K, Takahashi KG, Suzuki T: Identification and tissue expression analysis of $C$-type lectin and galectin in the Pacific oyster, Crassostrea gigas. Comp Biochem Physiol B, Biochem Mol Biol 2008, 149:168-175.

29. Mitta G, Hubert F, Noel T, Roch P: Myticin, a novel cysteine-rich antimicrobial peptide isolated from haemocytes and plasma of the mussel Mytilus galloprovincialis. Eur J Biochem 1999, 265:7|-78.

30. Qiu LM, Song LS, Xu W, Ni DJ, Yu YD: Molecular cloning and expression of a Toll receptor gene homologue from Zhikong Scallop, Chlamys farreri. Fish Shellfish Immunol 2007, 22:45 I-466.

31. Qiu LM, Song LS, Yu YD, Xu W, Ni DJ, Zhang QC: Identification and characterization of a myeloid differentiation factor $\mathbf{8 8}$ (MyD88) cDNA from Zhikong scallop Chlamys farreri. Fish Shellfish Immunol 2007, 23:614-623.

32. Yu YD, Qiu LM, Song LS, Zhao JM, Ni DJ, Zhang Y, Xu W: Molecular cloning and characterization of a putative lipopolysaccharide-induced TNF-alpha factor (LITAF) gene homologue from Zhikong scallop Chlamys farreri. Fish Shellfish Immunol 2007, 23:419-429.

33. Zhao JM, Song LS, Li CH, Ni DJ, Wu LT, Zhu L, Wang H, Xu W: Molecular cloning, expression of a big defensin gene from bay scallop Argopecten irradians and the antimicrobial activity of its recombinant protein. Mol Immunol 2007, 44:360-368.

34. Zhu L, Song LS, Zhao JM, Xu W, Chang YQ: Molecular cloning, characterization and expression of a serine protease with clip-domain homologue from scallop Chlamys farreri. Fish Shellfish Immunol 2007, 22:556-566.

35. Kang YS, Kim YM, Park KI, Cho SK, Choi KS, Cho M: Analysis of EST and lectin expressions in hemocytes of Manila clams (Ruditapes philippinarum) (Bivalvia: Mollusca) infected with Perkinsus olseni. Dev Comp Immunol 2006, 30: I I |9-I I3।

36. Gestal C, Costa MM, Figueras A, Novoa B: Analysis of differentially expressed genes in response to bacterial stimulation in hemocytes of the carpet-shell clam Ruditapes decussatus: Identification of new antimicrobial peptides. Gene 2007, 406: $134-143$.

37. Prado-Alvarez M, Gestal C, Novoa B, Figueras A: Differentially expressed genes of the carpet shell clam Ruditapes decussatus against Perkinsus olseni. Fish Shellfish Immunol 2009, 26:72-83.

38. Flom G, Behal RH, Rosen L, Cole DG, Johnson JL: Definition of the minimal fragments of Stil required for dimerization, interaction with $\mathrm{Hsp} 70$ and $\mathrm{Hsp} 90$ and in vivo functions. Biochem J 2007, 404: I59-I67.
39. David E, Tanguy A, Pichavant K, Moraga D: Response of the Pacific oyster Crassostrea gigas to hypoxia exposure under experimental conditions. FEBS J 2005, 272:5635-5652.

40. Dondero F, Piacentini L, Marsano F, Rebelo M, Vergani L, Venier P, Viarengo A: Gene transcription profiling in pollutant exposed mussels (Mytilus spp.) using a new low-density oligonucleotide microarray. Gene 2006, 376:24-36.

4I. Meistertzheim AL, Tanguy A, Moraga D, Thebault MT: Identification of differentially expressed genes of the Pacific oyster Crassostrea gigas exposed to prolonged thermal stress. FEBS J 2007, 274:6392-6402.

42. Wallin RPA, Lundqvist A, More SH, von Bonin A, Kiessling R, Ljunggren HG: Heat-shock proteins as activators of the innate immune system. Trends Immunol 2002, 23:130-135.

43. He NH, Qin QW, Xu X: Differential profile of genes expressed in hemocytes of White Spot Syndrome Virus-resistant shrimp (Penaeus japonicus) by combining suppression subtractive hybridization and differential hybridization. Antiviral Res 2005, 66:39-45

44. Anderson RS, Patel KM, Roesijadi G: Oyster metallothionein as an oxyradical scavenger: implications for hemocyte defense responses. Dev Comp Immunol I 999, 23:443-449.

45. Carrasco J, Hernandez J, Bluethmann H, Hidalgo J: Interleukin-6 and tumor necrosis factor-alpha type I receptor deficient mice reveal a role of IL-6 and TNF-alpha on brain metalIothionein-I and -III regulation. Brain Res Mol Brain Res 1998, 57:221-234.

46. Wang LL, Song LS, Ni DJ, Zhang H, Liu WQ: Alteration of metallothionein mRNA in bay scallop Argopecten irradians under cadmium exposure and bacteria challenge. Comp Biochem Physiol C Toxicol Pharmacol 2009, I 49:50-57.

47. Desclaux-Marchand C, Paul-Pont I, Gonzalez P, Baudrimont M, de Montaudouin $X$ : Metallothionein gene identification and expression in the cockle (Cerastoderma edule) under parasitism (trematodes) and cadmium contaminations. Aquat Living Resour 2007, 20:43-49.

48. Ong ST, Ho JZS, Ho B, Ding JL: Iron-withholding strategy in innate immunity. Immunobiology 2006, 2 I I :295-3I4.

49. Beck G, Ellis TW, Habicht GS, Schluter SF, Marchalonis J]: Evolution of the acute phase response: iron release by echinoderm (Asterias forbesi) coelomocytes, and cloning of an echinoderm ferritin molecule. Dev Comp Immunol 2002, 26: I I-26.

50. Ong DST, Wang LH, Zhu Y, Ho B, Ding JL: The response of ferritin to LPS and acute phase of Pseudomonas infection. J Endotoxin Res 2005, I I:267-280.

5I. Gauthier JD, Vasta GR: Inhibition of in vitro replication of the oyster parasite Perkinsus marinus by the natural iron chelators transferrin, lactoferrin, and desferrioxamine. Dev Comp Immunol 1994, 1 8:277-286.

52. Takahashi K, Mori K, Nomura T: Occurrence and characterization of lysozyme in the marine bivalves. Nippon Suisan Gakkai Shi 1986, 52:863-868.

53. Cronin MA, Culloty SC, Mulcahy MF: Lysozyme activity and protein concentration in the haemolymph of the flat oyster Ostrea edulis (L.). Fish Shellfish Immunol 200 I, I I:6 I I-622.

54. Ordás MC, Ordás A, Beloso C, Figueras A: Immune parameters in carpet shell clams naturally infected with Perkinsus atlanticus. Fish Shellfish Immunol 2000, 1 0:597-609.

55. Chu FLE, La Peyre JF: Perkinsus marinus susceptibility and defense-related activities in eastern oysters Crassostrea virginica - temperature effects. Dis Aquat Org 1993, 16:223-234.

56. Chu FLE, La Peyre JF, Burreson CS: Perkinsus marinus infection and potential defense related activities in eastern oysters, Crassostrea virginica - Salinity effects. I Invertebr Pathol 1993, 62:226-232.

57. La Peyre JF, Chu FLE, Meyers JM: Hemocytic and humoral activities of eastern and Pacific oysters following challenge by the protozoan Perkinsus marinus. Fish Shellfish Immunol 1995, 5:179-190.

58. Bulgakov AA, Park KI, Choi KS, Lim HK, Cho M: Purification and characterisation of a lectin isolated from the Manila clam Ruditapes philippinarum in Korea. Fish Shellfish Immunol 2004, 16:487-499.

59. Tasumi S, Vasta GR: A galectin of unique domain organization from hemocytes of the eastern oyster (Crassostrea virginica) 
is a receptor for the protistan parasite Perkinsus marinus. J Immunol 2007, I 79:3086-3098.

60. Fujita T, Endo Y, Nonaka M: Primitive complement system recognition and activation. Mol Immunol 2004, 4 I: I03- I I I.

61. Bender RC, Bayne C): Purification and characterization of a tetrameric alpha-macroglobulin proteinase inhibitor from the gastropod mollusc Biomphalaria glabrata. Biochem J 1996, 3 16:893-900.

62. Vaseeharan B, Lin YC, Ko CF, Chiou TT, Chen JC: Molecular cloning and characterisation of a thioester-containing alpha 2macroglobulin (alpha 2-M) from the haemocytes of mud crab Scylla serrata. Fish Shellfish Immunol 2007, 22: I I5- I 30.

63. Ma HM, Mai KS, Xu W, Liufu ZG: Molecular cloning of alpha2macroglobulin in sea scallop Chlamys farreri (Bivalvia, Mollusca). Fish Shellfish Immunol 2005, I 8:345-349.

64. Zhang H, Song LS, Li CH, Zhao JM, Wang H, Gao Q, Xu W: Molecular cloning and characterization of a thioester-containing protein from Zhikong scallop Chlamys farreri. Mol Immunol 2007, 44:3492-3500.

65. Kishore $U$, Reid $\mathrm{KBM}$ : CI q: structure, function, and receptors. Immunopharmacology 2000, 49: I59-I70.

66. Zhang H, Song LS, Li CH, Zhao JM, Wang H, Qiu U, Ni DJ, Zhang Y: A novel $\mathrm{Clq}$-domain-containing protein from Zhikong scallop Chlamys farreri with lipopolysaccharide binding activity. Fish Shellfish Immunol 2008, 25:28I-289.

67. Mitta G, Vandenbulcke F, Roch P: Original involvement of antimicrobial peptides in mussel innate immunity. FEBS Lett 2000 , 486: $185-190$.

68. Charlet M, Chernysh S, Philippe H, Hetru C, Hoffmann JA, Bulet P: Innate immunity - Isolation of several cysteine-rich antimicrobial peptides from the blood of a mollusc, Mytilus edulis. J Biol Chem 1996, 271:21808-21813.

69. Gueguen Y, Herpin A, Aumelas A, Garnier J, Fievet J, Escoubas JM, Bulet P, Gonzalez M, Lelong C, Favrel P, Bachere E: Characterization of a defensin from the oyster Crassostrea gigas - Recombinant production, folding, solution structure, antimicrobial activities, and gene expression. J Biol Chem 2006, 28 I:3 |3-323.

70. Gonzalez M, Gueguen Y, Desserre G, de Lorgeril J, Romestand B, Bachere E: Molecular characterization of two isoforms of defensin from hemocytes of the oyster Crassostrea gigas. Dev Comp Immunol 2007, 3 I:332-339.

7I. Saito T, Kawabata S, Shigenaga T, Takayenoki Y, Cho JK, Nakajima H, Hirata $M$, Iwanaga S: A novel big defensin identified in horseshoe crab hemocytes - isolation, amino acid sequence, and antibacterial activity. | Biochem 1995, I | 7: | |3 |- | | 37.

72. McCahill A, Warwicker J, Bolger GB, Houslay MD, Yarwood SJ: The RACKI scaffold protein: A dynamic cog in cell response mechanisms. Mol Pharmacol 2002, 62:1261-1273.

73. Ron D, Jiang Z, Yao LN, Vagts A, Diamond I, Gordon A: Coordinated movement of RACKI with activated beta IIPKC. I Biol Chem 1999, 274:27039-27046.

74. Vidya $N$, Thiagarajan $\mathrm{R}$, Arumugam $\mathrm{M}$ : In vitro generation of superoxide anion by the hemocytes of Macrobrachium rosenbergii: Possible mechanism and pathways. J Exp Zool Part A: Ecol Genet Physiol 2007, 307A:383-396.

75. Humphries JE, Yoshino TP: Regulation of hydrogen peroxide release in circulating hemocytes of the planorbid snail Biomphalaria glabrata. Dev Comp Immunol 2008, 32:554-562.

76. Hermanto U, Zong CS, Li WQ, Wang LW: RACKI, an insulin-like growth factor I (IGF-I) receptor-interacting protein, modulates IGF-I-dependent integrin signaling and promotes cell spreading and contact extracellular matrix. Mol Cell Biol 2002 , 22:2345-2365.

77. Siah A, Masson R, Loup B, Bultelle F, Pellerin J, Leboulenger F, Danger JM: Receptor activated $C$ kinase is down-regulated in the male gonad of the marine bivalve mollusc Mya arenaria exposed to tributyltin (TBT). Aquat Toxicol 2007, 83:295-305.

78. Arancibia SA, Beltran CJ, Aguirre IM, Silva P, Peralta AL, Malinarich F, Hermoso MA: Toll-like receptors are key participants in innate immune responses. Biol Res 2007, 40:97-II 2.

79. Chung JY, Park YC, Ye H, Wu H: All TRAFs are not created equal: common and distinct molecular mechanisms of TRAF-mediated signal transduction. J Cell Sci 2002, I | 5:679-688.

80. Kabsch W, Vandekerckhove J: Structure and function of actin. Annu Rev Biophys Biomol Struct 1992, 2 I:49-76.
81. Herman IM: Actin isoforms. Curr Opin Cell Biol 1993, 5:48-55

82. Jannotti-Passos LK, Andrade HM, Caldeira RL, Romanha AJ, Murta SMF, Chapeaurouge DA, Perales J, Coelho PMZ, Carvalho OS: Proteome analysis of the cardiac and pericardial tissue of Biomphalaria tenagophila populations susceptible and resistant to Schistosoma mansoni infection. Acta Trop 2008, 1 05:229-234.

83. Turnbull MW, Martin SB, Webb BA: Quantitative analysis of hemocyte morphological abnormalities associated with Campoletis sonorensis parasitization. J Insect Sci 2004, 4: I5.

84. Anderson RS, Luskey TM, Strauss MA: In vitro protease production by QPX (Abstract). J Shellfish Res 2006, 25:708.

85. Jain R, Raghukumar S, Tharanathan R, Bhosle NB: Extracellular polysaccharide production by thraustochytrid protists. Mar Biotechnol 2005, 7:184-192.

86. Qian H, Liu QQ, Allam B, Collier JL: Molecular genetic variation within and among isolates of QPX (Thraustochytridae), a parasite of the hard clam Mercenaria mercenaria. Dis Aquat Org 2007, 77:159-168.

87. Perrigault M, Buggé DM, Hao CC, Allam B: Modulatory effects of hard clam (Mercenaria mercenaria) tissue extracts on the in vitro growth of its pathogen QPX. J Invertebr Pathol 2009 , 100: I-8.

88. Buggé DM, Allam B: A fluorometric technique for the in vitro measurement of growth and viability in Quahog parasite unknown (QPX). J Shellfish Res 2005, 24: I013-1018.

89. Diatchenko L, Lau YFC, Campbell AP, Chenchik A, Moqadam F, Huang B, Lukyanov S, Lukyanov K, Gurskaya N, Sverdlov ED, Siebert PD: Suppression subtractive hybridization: A method for generating differentially regulated or tissue-specific cDNA probes and libraries. Proc Natl Acad Sci USA 1996, 93:6025-6030.

90. Livak KJ, Schmittgen TD: Analysis of relative gene expression data using real-time quantitative PCR and the 2(T)(-Delta Delta C) method. Methods 200I, 25:402-408.
Publish with Bio Med Central and every scientist can read your work free of charge

"BioMed Central will be the most significant development for disseminating the results of biomedical research in our lifetime. "

Sir Paul Nurse, Cancer Research UK

Your research papers will be:

- available free of charge to the entire biomedical community

- peer reviewed and published immediately upon acceptance

- cited in PubMed and archived on PubMed Central

- yours - you keep the copyright
BioMedcentral 